\title{
Evaluation of Salivary Alpha-Amylase level in Iraqi children with positive family history of hypertension
}

\author{
Rasha Abbas Azeez ${ }^{*}$, Suha Talal Abd ${ }^{2}$, Maysaa Kadhim Al-Malkey ${ }^{3}$, Sumaiah Ibraheem $^{*}$ \\ Hussein 4 \\ ${ }^{1 * 2,4}$ Department of Basic Sciences, College of Dentistry, University of Baghdad, Baghdad-Iraq \\ ${ }^{3}$ Tropical-Biological Research Unit, College of Science, University of Baghdad, Baghdad-Iraq \\ E- mail: ${ }^{2}$ suhatalal_abd@yahoo.com
}

(Received April 08, 2021; Accepted June 22, 2021; Available online August 28, 2021)

DOI: 10.33899/edusj.2000.168651, (C) 2021, College of Education for Pure Science, University of Mosul.

This is an open access article under the CC BY 4.0 license (http://creativecommons.org/licenses/by/4.0/).

\begin{abstract}
This study accomplished to determine levels of salivary Alpha-Amylase (sAA) in Iraqi children with positive family history of hypertension, Hypertension was believed to be a risk factor in $18 \%$ of all deaths in 2010 (9.4 million globally). This study included one hundred children from primary school aged 6 to 13 years, with a focus in child welfare and family health history, with an emphasis on close relatives' hypertension reputations, with hypertension close relatives record categories identified by 1 st and 2nd relatives, after documenting the full details, the burden was assessed for the children's families. The influence of age is confirmed by a correlation study of our own numbers, which shows a positive correlation. The disparity between age and salivary amylase level was important, with age group (12-13) years students having a higher mean salivary amylase level (309.7 U/L) than age group (6-7) years students (270.6 U/L). The gender outcome did not exceed statistical significance, but the gap was not important, which may be due to the limited sample size.
\end{abstract}

Keyword: Salivag Alpha-Amylase, high blood pressure.

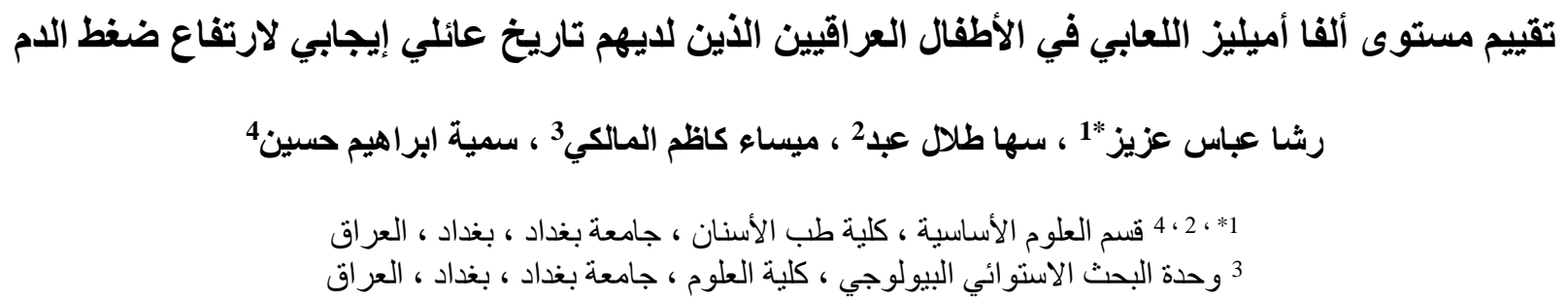

الخلاصة:

أنجزت هذه الدراسة لتحديد مستويات ألفا أميليز اللعابي (SAA) في الأطفال العراقيين الذين لديهم تاريخ عائلي إيجابي لارتفاع ضغط الدم ، ويعتقد أن ارتفاع ضغط الدم هو عامل خطر في 18 ٪ من جميع الوفيات في عام 2010 (9.4 مليون على مستوى العالم). تضمنت هذه الدراسة مائة طفل من المدرسة الابتدائية تتراوح أعمارهم بين 6 و 13 عامًا ، مع التركيز على رعائ رعائ الطفل والتاريخ الصحي للأسرة 


$$
\begin{aligned}
& \text { ، مع التركيز على سمعة ارتفاع ضغط الدم لدى الأقارب المقربين ، مع تصنيفات أقارب ارتفاع ضغط الدم التي حددها الأقارب الأول }
\end{aligned}
$$

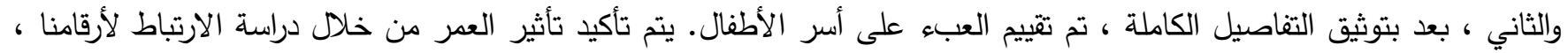

$$
\begin{aligned}
& \text { والتي تظهر ارتباطًا إيجابيًا. كان التفاوت بين العمر ومستوى الأميليز اللعابي مهمًا ، حيث كان لاى الطلاب في الفئة العمرية (12-13) } \\
& \text { عامًا مستوى أعلى من مستوى الأميلاز اللعابي (309.7 وحدة / لتز ) من طلاب الفئة العمرية (6-7) سنوات (270.6 وحدة / لتر) ـ لـ لم } \\
& \text { تتجاوز نتيجة الجنس دلالة إحصائية ، لكن الفجوة لم تكن مهمة ، والتي قد تكون بسبب حجم العينة المحدود. } \\
& \text { الكلمات المفتاحية : اللعاب ،ألفا أميليز ، ارتفاع ضغط الدم }
\end{aligned}
$$

\section{Introduction}

One of the most important enzymes produced and secreted by salivary gland cells that respond to norepinephrine. Salivary Alpha-Amylase (sAA) is a bacterial defense enzyme that that catalyzes the hydrolysis reaction of starch and glycogen. Low sAA activity is linked to a higher risk of oral infection $[1,2]$. However, the use of sAA as a recent and effective instrument in the diagnosis of hypertension clinically and the determination of hyperactivity of sympathetic which thought to add to our understanding of the hyperadrenergic condition's functional role in hypertension. Non-pharmacological treatments are also thought to be effective or pharmacological interventions in the treatment of hypertension will open up new possibilities as a non-invasive determinant for studying sympathetic dysfunction [3, 4, and 5]. As a result, developing novel biomarkers to determine sympathetic behavior is of considerable concern in order to investigate the mechanisms of sympathetic activation from various perspectives Since saliva sampling is non-invasive, easy, and inexpensive, salivary biomarkers have piqued interest. It has been proposed that Stress-related sympathetic activity in response to psychological and physiological stimuli is reflected by the salivary enzyme alpha-amylase (sAA) [6, 1, 7 and 8]. The interested reader is pointed to Humphrey and Williamson (2001) for a detailed explanation of saliva flow and composition [9]. Regardless of the fact that several studies support sAA as a possible surrogate marker for sympathetic behavior, there's still some disagreement about its own utility, primarily whether sAA levels represent a combination of sympathetic and simultaneous parasympathetic activity instead of sympathetic activation alone [10,11]. There are two forms of elevated blood pressure: primary and secondary hypertension [12]. In 90-95 percent of cases, high blood pressure is caused by a person's diet and genetic factors $[12,13]$. Excess salt in the system can be affected by a number of factors, including a high-salt diet, alcohol intake, smoking, and being overweight. Secondary hypertension, which affects (510) $\%$ of all cases, is described as hypertension. Chronic kidney disease, endocrine abnormalities, birth control pill use, and diminished arterial renal vessels are also things to think about [12]. Blood pressure is measured using the systolic and diastolic pressures, as well as the mean and low pressures. For most adults, normal blood pressure is between $100-130 \mathrm{~mm} \mathrm{Hg}(\mathrm{mm} \mathrm{Hg}$ ) systolic and 60-80 $\mathrm{mm} \mathrm{Hg}$ diastolic at rest. If your resting blood pressure is greater than $130 / 80$ or $140 / 90 \mathrm{mmHg}$, you probably have elevated blood pressure [12,14]. Various numbers refer to various children[15]. Lowering blood pressure and reducing the chance of cardiovascular problems can be achieved by making lifestyle modifications and taking prescriptions. Reduced alcohol consumption, increased physical exercise, weight loss, a well-balanced diet, and lower salt intake are also examples of lifestyle changes. If lifestyle changes aren't enough Medications to lower blood pressure are used. In 90\% of cases, three drugs are sufficient to keep blood pressure under control. Around $16 \%$ and $37 \%$ of the world's population suffers from low blood pressure [16]. Hypertension was thought to be the cause of $18 \%$ of all deaths (9.4 million worldwide) in 2010[17]. 
Heart disease and stroke are the first and second 1 Cardiovascular diseases (CVD) causes that leading to death in the United States [18]. Blood pressure that is elevated during childhood and adolescence is believed to be a precursor to excessive blood pressure later in life [19, 20]. Cardiovascular Disease (CVD). According to recent figures, 71 million Americans (or 35\% of the population) have a kind of CVD (Congenital heart problems, as well as heart disease, stroke, heart attack, or elevated blood pressure) Total cholesterol levels of more than $200 \mathrm{mg} / \mathrm{dL}$ are seen in around $10 \%$ of adolescents aged 12 to 19 , which is a significant risk factor for CVD [21]. Systolic blood pressure (SBP) and/or diastolic blood pressure (DBP) are used to characterize high blood pressure in children and teenagers (DBP) That is, the youth's age, gender, and height are all in the 95th percentile. In children and teenagers, prehypertension is described as a blood pressure reading between the (90-95) \%. This has been attributed to an increased risk of hypertension.[18]

According to numerous published studies [22,23,24], Although biomarker advances, comprehensive clinical trials are needed to validate salivary biomarkers for CVD and its various clinical stages. In order to predict disease in real people over time, family history is paired in combination with the other wellknown risk factors (absolute risk). Infants and persons with a positive family history of high blood pressure can exhibit early warning signs of lipid profile disturbances, high HDL cholesterol, elevated triglyceride levels, and gestational diabetes [25,26]. Research teams from the Framingham Study showed that developing CVD in at least one parent doubled the 8-year risk of CVD in men and boosted the risk of CVD in women by $70 \%$. [27, 28]. Although family history has been shown to play a role in the risk of diabetes and cardiovascular disease, it is now commonly used to calculate that risk quantitatively. When it is, family history is commonly used to rank subgroups within a population based on one group's higher prevalence than another (relative risk) [29, 30]. This study aimed to investigate the correlations of sAA (Salivary Alpha-Amylase) levels of hypertension in Iraqi positive family history children. The presence of symptoms Since the system has had only a short time to function, the presence of adult chronic diseases in children means that genetic factors are significant.

\section{Research Method}

This study included one hundred children from primary school aged 6 to 13 years, with a focus in child welfare. and family health history, with an emphasis on close relatives' hypertension reputations, with hypertension close relatives record categories identified by 1 st and 2 nd relatives. A standardized questionnaire was circulated in Arabic language and sent to close relatives' representatives of each student, child health history and family health background, focusing on close relatives' credibility of hypertension, with hypertension close relatives record categories identified by 1 st and second relative's, the strain was assessed for the children's families after documenting all of the data. Using disposable plane dental mirrors and probes, a clinical oral test was performed under natural light. According to Löe (1967),[31], gingival health status was calculated by the gingival index (GI). The bleeding is assessed by probing gently along the wall of soft tissue of the gingival sulcus. The scores of the four areas of the tooth can be summed and divided by four to give the GI for the tooth. The GI of the individual can be obtained by adding the values of each tooth and dividing by the number of teeth examined. The Gingival Index may be scored for all surfaces of all or selected teeth or for selected areas of all or selected teeth. The GI may be used for the assessment of prevalence and severity of gingivitis in populations, groups and individuals. A score from 0.1-1.0 = mild inflammation; 1.1-2.0 = moderate inflammation from, and 2.1-3.0 signifies severe inflammation. The GI has been used frequently in clinical trials of therapeutic agents The sensitivity and reproducibility is good provided the examiner's knowledge of periodontal biology and pathology is optimal (Löe, 1967). Saliva was collected from both members under the same circumstances after a 
therapeutic oral review. The strain was assessed for the children's families after documenting all of the data. Using disposable plane dental mirrors and probes, a clinical oral test was performed under natural light. According to Le (1967) [31]. Saliva was collected from both members under the same circumstances after a therapeutic oral review. Salivary flow rate was measured in milliliters per second after the salivary froth had disappeared. Before they were checked, the samples were held at $-80^{\circ} \mathrm{C}$. The sampling sessions were limited to the hours of 9:00 and 11:00 a.m. to minimize the influence of diurnal variations. The concentration of salivary amylase was calculated using Saliva Analysis Quantitative Colorimetric Amylase Dedication at 585nm. Bio-assay Systems' Enzy Chrom TM-Amylase Analysis Kit (ECAM-100) (USA).

SPSS version 19.0 was used for the statistical analysis (SPSS Inc; Chicago, IL, USA). The following methods were used: descriptive statistical analysis, study of variation (ANOVA), student T-test, and straight line and several straight-line connections. Mathematical significance was defined as a $p$-value of less than 0.05 .

\section{Blood pressure assessment}

The participants' systolic and diastolic blood pressures were measured in their left arm as they sat upright. The general practitioner assessed the patient using the procedure of Riva-Rocci (Boso sphygmomanometer, Germany). Real standards (World Health Organization-International Society of Hypertension). Hypertension Management Guidelines are a set of recommendations for treating hypertension. Participants were graded as hypertensive whether their systolic BP was $140 \mathrm{mmHg}$ or their diastolic BP was $90 \mathrm{mmHg}$ (Guidelines Subcommittee, 1999).

\section{Results}

Table (1): Salivary Alpha- Amylase levels in children with mild and moderate gingival index

\begin{tabular}{|l|l|l|l|l|c|}
\hline \multirow{2}{*}{ Gingival index } & \multicolumn{5}{|c|}{ Salivary Amylase U/L } \\
\cline { 2 - 5 } & Mean & SD & SE & N & P \\
\hline Mild (0.1 -1) & 281.9 & 41.3 & 6.5 & 40 & \\
\hline Moderate (1.1-2) & 291.1 & 36.5 & 4.3 & 73 & \multirow{2}{*}{$0.22[$ NS] } \\
\hline
\end{tabular}

The difference in mean salivary amylase levels between children with mild (0.1 -1) gingivitis $(281.9 \pm 41.3)$ and those with higher gingival indexes was not significant, as seen in table 1 . The gingival index in this study was divided into two categories: mild and severe, and the majority of sample participants falling into the moderate score range $(291.1 \pm 36.5)$, though the mean variations were not significant with the $\mathrm{P}$ value $(0.22)$.

Table (2): Salivary Alpha- Amylase level according to age group of children

\begin{tabular}{|l|l|l|l|l|l|}
\hline \multirow{2}{*}{ Age group (years) } & \multicolumn{4}{|c|}{ Salivary Amylase U/L } \\
\cline { 2 - 6 } & Mean & SD & SE & N & P \\
\hline $6-7$ & 270.6 & 41.0 & 7.6 & 29 & \\
\hline $10-9$ & 281.2 & 35.9 & 6.1 & 35 & $<0.001$ \\
\hline $12-13$ & 300.6 & 34.1 & 5.8 & 34 & \\
\hline
\end{tabular}


The sample's key characteristics are shown in Table 2. There are four classes, for both sexes, according to the factorial configuration (current blood pressure level [high vs. low]) The control group has a high blood pressure and is not taking any antihypertensive drugs (AD). The influence of age is confirmed by a correlation study of our own results, which shows a positive correlation between age and salivary Amylase Level. The table also revealed that students in the age group (12-13) years had a significantly higher mean salivary amylase level (309.7 U/L) than students in the age group (6-7) years (270.6 U/L). The gender outcome did not exceed statistical significance, but the gap was not important, which may be due to the limited sample size.

Table (3): Family history of high Blood Pressure and Salivary Alpha- Amylase Level.

\begin{tabular}{|l|l|l|l|l|l|}
\hline \multirow{2}{*}{ Family history (Hypertension) } & \multicolumn{5}{|c|}{ Salivary Amylase U/L } \\
\cline { 2 - 6 } & Mean & SD & SE & N & P \\
\hline Negative & 272.0 & 57.8 & 12.9 & 20 & \\
Positive first degree & 297.7 & 37.4 & 7.8 & 23 & \multirow{2}{*}{$0.08[$ NS] } \\
\hline Positive second degree & 288.9 & 30.0 & 3.6 & 71 & \\
\hline
\end{tabular}

Children with a positive family history of elevated blood pressure have a higher salivary amylase level than people with a poor family history (297.7) U/L vs.( 272.0)U/L, according to the findings of table of (3).

Table (4): Multiple linear regression model with salivary Amylase concentration was used as the dependent variable, along with a number of explanatory variables.

\begin{tabular}{|l|l|l|l|}
\hline & partial regression coefficient & $\mathbf{P}$ & Standardized regression coefficient \\
\hline (Constant) & 224.534 & $<0.001$ & \\
\hline Gingival index & 36.541 & $0.19[\mathrm{NS}]$ & .128 \\
\hline Age & 5.180 & 0.02 & .273 \\
\hline Gender & -10.644 & $0.15[\mathrm{NS}]$ & -.137 \\
\hline Family history (Hypertension) & -9.262 & $0.22[\mathrm{NS}]$ & -.117 \\
\hline
\end{tabular}

$\mathrm{R} 2=\mathbf{0 . 2 0 5} \quad \mathrm{P}($ Model $)=\mathbf{0 . 0 0 5}$

The explanatory variables are gingival index, age, and gender, as seen in table (4). After correcting for the other explanatory variables in the model, only age displayed The level of salivary alpha- amylase has a statistically important positive correlation. Per year of age, the Salivary alpha- amylase level is expected to increase by an average of 5.2 units.

\section{Discussion}

Since the climate has only had a limited period to function, the presence of symptoms which denote presence of adult chronic diseases in children means that genetic conditions play a role. Environmental factors are also at hand, as shown by the recent rapid decrease in diet and physical activity patterns. At the conclusion of the report, total cholesterol levels, SBP and DBP, and BMI did not differ significantly between those in the intervention or control schools., according to a study undertaken by Nader PR, et al 1999; Webber LS 1996 [32,33]. 


\section{Journal of Education and Science (ISSN 1812-125X), Vol: 30, No: 3, 2021 (13-20) \\ Special Issue for Proceeding of $3^{\text {rd }}$ National (1st international conference of biology) (ICBSUM 2021) 5, 6 July College of Education for Pure Science, University of Mosul, Mosul, Iraq.}

The Dietary Intervention Study in Children was a randomized controlled trial that took place outside of school, LDL-cholesterol levels in children aged 8 to 10 years old were elevated that studied in a randomized controlled trial [34]. Elevated blood pressure during infancy and puberty is thought to be an indicator of high blood pressure later in life[19,20] .

For the youth's age, gender, and height, a systolic blood pressure (SBP) and/or diastolic blood pressure (DBP) at or above the 95th percentile is considered high blood pressure in children and adolescents. (i.e., a blood pressure that is slightly higher than average but not high enough to be classified as hypertension); this is linked to an elevated chance of experiencing hypertension[18 ]

Adults can lower their risk of premature mortality and events by reducing or treating heart disease and stroke risk factors. For instance, studies conducted in Veterans Administration hospitals Treatment for high blood pressure resulted in fewer cases of stroke, heart disease, and worsening hypertension in the 1960s [35, 36]. Over a four-year duration, a reduction in SBP of 12 to $13 \mathrm{~mm} \mathrm{Hg}$ was associated with a $21 \%$ reduction in CHD, a $37 \%$ reduction in stroke, a $25 \%$ reduction in total cardiovascular mortality, and a $13 \%$ reduction in all-cause mortality[37]. According to some research, a $10 \%$ reduction in serum cholesterol concentrations reduces the risk of heart attacks by 30\% [38]. Diet, cigarette consumption, physical exercise, family history, height, weight, and blood pressure are all assessed by the American Heart Association. Obesity, asthma, dyslipidemia, diabetes, and early CVD (onset age for men 55 years and 65 years for women) can all be considered in the presence of first-degree kin. Family history should be taken into account before screening and treating children for high cholesterol and other risk factors $[39,40,41]$. The US Preventive Services Task Force found that routine screening for elevated blood pressure or obesity in children and teenagers would decrease their risk of cardiovascular disease.

\section{Conclusion}

There was a positive correlation between age of children with positive family history of high blood pressure and salivary amylase level, while there was no correlation of between gender and salivary amylase level for the same children.

\section{References}

1. Granger DA, Kivlighan KT, El-Sheikh M, et al. Salivary alpha-Amylase in biobehavioral research: recent developments and applications. Ann NY Acad Sci 2007;1098:122-44. [PubMed] [Google Scholar].

2. Nater UM, Rohleder N. Salivary alpha-amylase as a non-invasive biomarker for the sympathetic nervous system: current state of research. Psychoneuroendocrinology 2009;34:486-96. [PubMed] [Google Scholar]

3. Strahler J, Kirschbaum C, Rohleder N. Association of blood pressure and antihypertensive drugs with diurnal alpha-amylase activity. Int J Psychophysiol. 2011;81:31-7.

4. Lakshmi PV, Sridevi E, Sai Sankar AJ, et al. Diagnostic perspective of saliva in insulin dependent diabetes mellitus children: An in vivo study. Contemp Clin Dent. 2015;6:443-7.

5. Ozdemir A, Sagkan RI, Karahan AY and Ordahan B. Evaluation of salivary alpha-amylase activity after stroke. Medicine Science J. 2019; 8(4):852-6.

6. Chatterton Jr., R.T., Vogelsong, K.M., Lu, Y.C., Ellman, A.B., Hudgens, G.A., 1996. Salivary alpha-amylase as a measure of endogenous adrenergic activity. Clin. Physiol. 16, 433-448.

7. Nater, U.M., 2004. The Role of Salivary Alpha-Amylase in Stress Research. Cuvillier, Goettingen, Germany.

8. Rohleder, N., Nater, U.M., Wolf, J.M., Ehlert, U., Kirschbaum, C., 2004. Psychosocial stress-induced activation of salivary alpha-amylase — an indicator of sympathetic activity? Ann. N. Y. Acad. Sci. 1032, 258-263. 
9. Humphrey, S.P., Williamson, R.T., 2001. A review of saliva: normal composition, flow, and function. J. Prosthet. Dent. 85, 162-169.

10. Bosch, J.A., Veerman, E.C., de Geus, E.J., Proctor, G.B., 2011. $\alpha$-Amylase as a reliable and convenient measure of sympathetic activity: don't start salivating just yet! Psychoneuro endocrinology 36, 449-453.

11. Strahler, J, Kirschbaum, Rohleder, N., 2011. Association of blood pressure and antihypertensive drugs with diurnal alpha-amylase activity. International Journal of Psychophysiology 81, 31-37.

12. Poulter NR, Prabhakaran D, Caulfield M (August 2015). "Hypertension". Lancet. 386 (9995): 801- 12. doi:10.1016/s0140-6736(14)61468-9. PMID 25832858.

13. Carretero OA, Oparil S (January 2000). "Essential hypertension. Part I: definition and etiology". Circulation. 101 (3): 329-35. doi:10.1161/01.CIR.101.3.329. PMID 10645931.

14. Whelton PK, Carey RM, Aronow WS, Casey DE, Collins KJ, Dennison Himmelfarb C, DePalma SM, Gidding S, Jamerson KA, Jones DW, MacLaughlin EJ, Muntner P, Ovbiagele B, Smith SC, Spencer CC, Stafford RS, Taler SJ, ThomasRJ, WilliamsK, WilliamsonJ, WrightT (June2018). "2017ACC/ AHA /AAPA /ABC /ACPM /AGS /APhA/ASH/ASPC/NMA/PCNA Guideline for the Prevention, Detection, Evaluation, and Management of High Blood Pressure in Adults: A Report of the American College of Cardiology/American Heart Association Task Force on Clinical Practice Guidelines". Hypertension. 71 (6): e13-e115.

15. James PA, Oparil S, Carter BL, Cushman WC, Dennison-Himmelfarb C, Handler J, Lackland DT, LeFevre ML, MacKenzie TD, Ogedegbe O, Smith SC, Svetkey LP, Taler SJ, Townsend RR, Wright JT, Narva AS, Ortiz E (February 2014). "2014 evidence-based guideline for the management of high blood pressure in adults: report from the panel members appointed to the Eighth Joint National Committee (JNC 8)". JAMA. 311 (5): 50720. doi:10.1001/jama.2013.284427. PMID 24352797.

16. Mancia G, Fagard R, Narkiewicz K, Redon J, Zanchetti A, Böhm M, et al. (July 2013). "2013 ESH/ESC guidelines for the management of arterial hypertension: the Task Force for the Management of Arterial Hypertension of the European Society of Hypertension (ESH) and of the European Society of Cardiology (ESC)". European Heart Journal. 34 (28): 2159-219. doi:10.1093/eurheartj/eht151. PMID 23771844.

17. Campbell NR, Lackland DT, Lisheng L, Niebylski ML, Nilsson PM, Zhang XH (March 2015). "Using the Global Burden of Disease study to assist development of nation-specific fact sheets to promote prevention and control of hypertension and reduction in dietary salt: a resource from the World Hypertension League". Journal of Clinical Hypertension. 17 (3): 165-7. doi:10.1111/jch.12479. PMID 25644474.

18. National High Blood Pressure Education Program Working Group on High Blood Pressure in Children and Adolescents. The fourth report on the diagnosis, evaluation, and treatment of high blood pressure in children and adolescents. Pediatrics.2004;114(2 suppl):555-576

19. Lauer RM, Mahoney LT, Clarke WR. Tracking of blood pressure during childhood: the Muscatine Study. Clin Exp Hypertens A. 1986;8:515-537

20. Bao W, Threefoot SA, Srinivasan SR, Berenson GS. Essential hypertension predicted by tracking of elevated blood pressure from childhood to adulthood: the Bogalusa Heart Study. Am J Hypertens. 1995;8:657-665

21. Thom T, Haase N, Rosamond W, et al. Heart disease and stroke statistics: 2006 update - a report from the American Heart Association Statistics Committee and Stroke Statistics Subcommittee [published corrections appear in Circulation. 2006;113: e696; and Circulation. 2006;114:e630]. Circulation. 2006;113: e85-e151

22. Meurman JH. Infectious and dietary risk factors of oral cancer. Oral Oncol. 2010

23. Floriano PN, Christodoulides N, Miller CS, et al. Use of saliva-based nano-biochip tests for acute myocardial infarction at the point of care: a feasibility study. Clin Chem 2009;55(8):1530-1538. [PubMed: 19556448]

24. Qvarnstrom M, Janket S, Jones JA, et al. Salivary lysozyme and prevalent hypertension. J Dent Res 2008;87(5):480-484. [PubMed: 18434581]

25. Dallo FJ, Weller SC. Effectiveness of diabetes mellitus screening recommendations [published correction appears in Proc Natl Acad Sci U S A. 2003;100:13116]. Proc Natl Acad Sci U S A. 2003;100:10574-10579

26. Hunt SC, Gwinn M, Adams TD. Family history assessment. Strategies for Prevention of Cardiovascular Disease Am J Prev Med. 2003;24:136-142 
27. Lloyd-Jones DM, Nam BH, D'Agostino RB Sr, et al. Parental cardiovascular disease as a risk factor for cardiovascular disease in middle-aged adults: a prospective study of parents and offspring. JAMA. 2004;291:2204-2211.

28. Murabito JM, Pencina MJ, Nam BH, et al. Sibling cardiovascular disease as a risk factor for cardiovascular disease in middle-aged adults. JAMA. 2005;294:3117-3123 16380592.

29. Scheuner MT, Wang SJ, Raffel LJ, Larabell SK, Rotter JI. Family history: a comprehensive genetic risk assessment method for the chronic conditions of adulthood. Am J Med Genet. 1997;71:315-324.

30. Rodolfo Valdez et al., "Is Family History a Useful Tool for Detecting Children at Risk for Diabetes and Cardiovascular Diseases? A Public Health Perspective.," Pediatrics 120 Suppl 2 (2007), doi:10.1542/peds.2007-1010G.

31. Löe H,The gingival index , the plaque index and the retention index systems. J Periodontology.1967;38 Issue 6.

32. Nader PR, Stone EJ, Lytle LA, et al. Three-year maintenance of improved diet and physical activity: the CATCH cohort. Child and Adolescent Trial for Cardiovascular Health. Arch Pediatr Adolesc Med. 1999; 153: 695-704

33. Webber LS, Osganian SK, Feldman HA, et al. Cardiovascular risk factors among children after a 2 1/2-year intervention: the CATCH Study. Prev Med. 1996; 25: 432-441

34. Obarzanek E, Kimm SY, Barton BA, et al. Long-term safety and efficacy of a cholesterol-lowering diet in children with elevated low-density lipoprotein cholesterol: seven-year results of the Dietary Intervention Study in Children (DISC). Pediatrics. 2001; 107:256-264

35. Veterans Administration Cooperative Study Group on Antihypertensive Agents. Effects of treatment on morbidity in hypertension: results in patients with diastolic blood pressures averaging 115 through $129 \mathrm{~mm} \mathrm{Hg}$. JAMA. 1967;202:1028-1034

36. Veterans Administration Cooperative Study Group on Antihypertensive Agents. Effects of treatment on morbidity in hypertension, II: results in patients with diastolic blood pressure averaging 90 through $114 \mathrm{~mm}$ Hg. JAMA. 1970;213: 1143-1152

37. He J, Whelton PK. Elevated systolic blood pressure and risk of cardiovascular and renal disease: overview of evidence from observational epidemiologic studies and randomized controlled trials. Am Heart J. 1999;138(3 pt 2):211-219

38. Cohen JD. A population-based approach to cholesterol control. Am J Med. 1997;102:23-25

39. Kavey RE, Daniels SR, Lauer RM, et al. American Heart Association guidelines for primary prevention of atherosclerotic cardiovascular disease beginning in childhood. J Pediatr. 2003; 142:368-372.

40. Williams CL, Hayman LL, Daniels SR, et al. Cardiovascular health in childhood: a statement for health professionals from the Committee on Atherosclerosis, Hypertension, and Obesity in the Young (AHOY) of the Council on Cardiovascular Disease in the Young, American Heart Association [published correction appears in Circulation. 2002;106:1178]. Circulation. 2002; 106:143-160.

41. Krebs NF, Jacobson MS; American Academy of Pediatrics, Committee on Nutrition. Prevention of pediatric overweight and obesity. Pediatrics. 2003;112:424-430. 